\title{
DynamicSainT
}

Jilid. V No. 1., April 2020

\section{STUDI PERKUATAN LERENG TERHADAP KELONGSORAN PADA RUAS JALAN TAMBA NARANG}

\author{
Ermitha Ambun RD ${ }^{1}$, Edgard Londong Allo², Irwanto $^{3}$ \\ Program Studi Teknik Sipil, Fakultas Teknik, Universitas Kristen Indonesia Toraja. \\ Jl. Nusantara No. 12,Makale, Tana Toraja, Sulawesi Selatan \\ 1ambun.rombe@gmail.com, ${ }^{2}$ edgard.londongallo2014@gmail.com, ${ }^{3}$ irwanto2014@gmail.com
}

\begin{abstract}
ABSTRAK
Lereng yang tidak stabil sangatlah berbahaya terhadap lingkungan sekitarnya, oleh sebab itu analisis stabilitas lereng sangat diperlukan. Pada kasus ini kondisi jalan poros Makale - Ulusalu tepatnya ruas jalan di Tamba'narang mengalami kelongsoran pada badan jalan.Tujuan studi ini adalah melakukan analisis stabilitas lereng pada kondisi awal sebelum menggunakan perkuatan dinding penahan tipe kantilever dan analisis stabilitas terhadap guling, analisa kestabilan terhadap geser dan stabilitas terhadap keruntuhan kapasitas daya dukung tanah setelah perkuatan menggunakan dinding penahan Kantilever. Metode yang digunakan untuk menganalisis perkuatan lereng adalah penyeledikan lapangan, uji karakteristik fisik tanah di laboratorium dan pengolahan data hasil pengamatan lapangan dan hasil uji laboratorium. Hasil analisa yang dilakukan diperoleh nilai faktor aman pada kondisi awal sebesar 0.82. Perencanaan perkuatan tanah metode coulomb adalah dengan menggunakan dinding penahan tipe kantilever dimana analisa kestabilan tanah dengan cara coulomb untuk tekanan tanah lateral di peroleh koefisien tekanan tanah aktif, Ka $=0.321$ dan koefisien tekanan tanah pasif, Kp = 5.193, untuk tekanan tanah aktif pada dinding penahan, $\mathrm{Pa}=150.97 \mathrm{kN} / \mathrm{m}$ dan tekanan tanah pasif pada dinding penahan, $P p=72.67 \mathrm{kN} / \mathrm{m}$. Untuk perencanaan dinding penahan tanah dengan cara Coulomb diperoleh nilai faktor keamanan terhadap guling adalah $\mathrm{Fgl}=2.91$ (Aman), Untuk analisa terhadap gaya geser adalah $\mathrm{Fgs}$ $=3.39$ (Aman) dan nilai faktor keamanan terhadap keruntuhan kapasitas daya dukung tanah adalah adalah FK $=8.2$ (Aman).
\end{abstract}

Kata Kunci: Dinding Penahan Tanah, Faktor Keamanan, Longsor, Perkuatan Lereng

\section{PENDAHULUAN}

Berbagai ancaman bencana yang tidak dapat di prediksi, sehingga sebagian besar masyakat di daerah rawan bencana alam sudah sewajarnya mempersiapkan diri dalam melindungi diri dari ancaman bencana alam untuk meminimalisir korban jiwa maupun kerugian material serta infrastruktur. Salah satu bencana alam yang sering terjadi yaitu tanah longsor. Tanah longsor adalah perpindahan massa tanah atau batuan dengan arah miring dari kedudukan semula akibat gaya gravitasi (Sutikno dkk, 2002).

Longsoran merupakan salah satu jenis gerakan massa tanah dan batuan atau pencampuran keduanya, menuruni atau keluar lereng akibat terganggunya kestabilan tanah atau batuan penyusun lereng tersebut. Faktor pemicu terjadinya longsor seperti peningkatan kandungan air tanah akibat tingginya intensitas hujan, dimana air meresap masuk ke dalam tanah sehingga tanah tidak memiliki kekuatan dan sangat mudah terbawah oleh aliran air dan menyebabkan terjadinya longsor (Jacob, 2019).

Kampung Tamba' Narang, Lembang Buri Kecamatan Rembon Kabupaten Tana Toraja terletak di daerah pegunungan merupakan salah sata diantara beberapa ruas jalan yang sangat rawan terhadap longsor. Beberapa ruas jalan di Kampung Tamba' Narang, Lembang Buri' yang menghubungkan Kampung Tamba' Narang dan daerah sekitarnya berada di pegunungan, sehingga bila terjadi hujan dengan intensitas tinggi kemungkinan longsor pada lereng sangat besar. Pada tahun tahun 2019 terjadi longsor pada ruas jalan Makale - Ulusalu 


\section{DynamicSainT}

Jilid. V No. 1., April 2020

tepatnya di Kampung Tamba' Narang, sehingga sangat mengganggu kelancaran arus lalu lintas merupakan ruas jalan utama yang menghubungkan Kampung Tamba' Narang dengan daerah di sekitarnya. Daya dukung tanah pada daerah longsoran tersebut perlu diketahui sehingga kita dapat mengetahui penyebab utama dari kelongsoran tanah. Sangat perlu dilakukan peninjauan tanah agar dapat meminimalisir kerusakan yang terjadi dan memberikan solusi bagi penanganan longsor yang terjadi.

\section{KAJIAN PUSTAKA}

\subsection{Tanah Longsor}

Tanah longsor adalah gerakan massa tanah dalam upaya mencari suatu keseimbangan akibat adanya gangguan keseimbangan dari luar sehingga menyebabkan berkurangnya kuat geser tanah dan meningkatnya tegangan tanah (Suryolelono, 2002). Menurut Hardiyatmo (2018), kelongsoran dapat terjadi disebabkan beberapa hal antara lain :

1. Penambahan beban lereng;

2. Penggalian atau pemotongan tanah pada kaki lereng;

3. Penggalian yang mempertajam kemiringan lereng;

4. Perubahan posisi muka air secara cepat;

5. Kenaikan tekanan lateral oleh air;

6. Gempa bumi atau getaran berlebihan;

7. Penurunan tahanan geser tanah pembentuk lereng oleh akibat kenaikan kadar air, kenaikan tekanan air pori, tekanan rembesan dan sifat kembangsusut tanah

\subsection{Penanggulangan Longsor}

Salah satu ciri negara berkembang Menurut Fathani (2007), penanggulangan tanah lonsor dapat dibagi dua kategori yaitu :

a. control work yaitu penanggulangan longsor dengan mengendalikan faktor penyebab longsor seperti kemiringan lereng dan air tanah. Kemirinan lereng dapat dilandaikan dengan melakukan usaha galian dan timbunan. Sedangkan air tanah dapat dikendalikan dengan sistem drainase untuk mengurangi infiltrasi.

b. restrain work yaitu penanganan longsor dengan menambahkan gaya penahan longsor misalnya dengan membuat dinding penahan tanah, dinding turap, angkur maupun pondasi tiang.

\subsection{Stabilitas Lereng}

Analisis stabilitas lereng umumnya didasarkan pada konsep keseimbangan plastis batas (limit plastic equilibrium). Analisa stabilitas dilakukan untuk menentukan faktor aman dari bidang longsor yang potensial. Kelongsoran pada lereng akan terjadi dalam suatu bidang lengkungan. Untik menghitung stabilitas, lengkungan yang ril ini diandaikan seperti lingkaran spiral logaritma (circle of logarithmic spiral) yang disebut sebagai bidang gelincir.

Terdapat dua jenis dasar kelongosoran yang terjadi pada lereng terbatas, yaitu :

1. keruntuhan lereng yaitu keruntuhan terjadi sepanjang gelincir yang masih terletak dalam batas lereng;

2. keruntuhan dasar, bila bidang gelincir melewati ujung bawah lereng, disebut keruntuhan dasar.

3. keruntuhan ujung kaki (pada ujung bawah lereng).

\subsection{Dinding Penahan Tanah}

Salah upaya yang dapat dilakukan untuk menanggulangi kelongsoran yaitu membuat dinding penahan tanah. Dinding penahan tanah merupakan konstruksi yang digunakan untuk menahan tanah lepas atau alami sehingga dapat mencegah keruntuhan tanah yang miring atau lereng yang kemantapannya tidak dapat dijamin oleh lereng tanah itu sendiri. Tanah yang tertahan memberikan dorongan secara aktif pada struktur dinding sehingga struktur cenderung akan terguling atau akan tergeser. 


\section{DynamicSainT}

Jilid. V No. 1., April 2020

Menurut Hadiyatmo (2014), berdasarkan cara untuk mencapai stabilitasnya, maka dinding penahan tanah dapat digolongkan dalam beberapa jenis yaitu :

a. dinding gravitasi, dimana dinding ini dibuat dari beton tidak bertulang atau pasangan batu, terkadang pada dinding jenis ini dipasang tulangan pada permukaan dinding untuk mencegah retakan permukaan akibat perubahan temperatur;

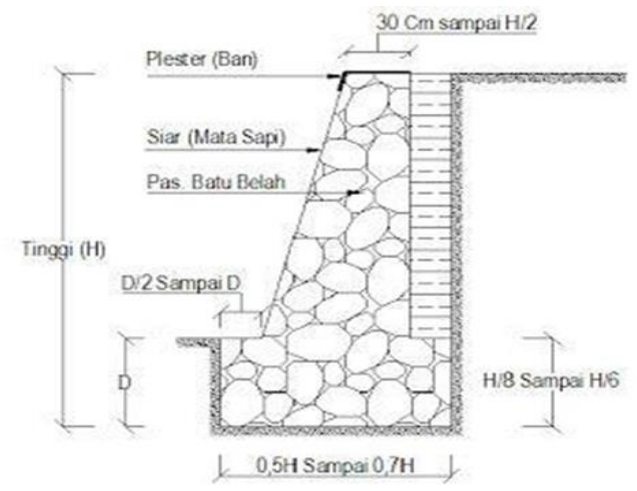

Gambar 1. Dinding Penahan Tanah Type Gravitasi (Sumber : Hardiyatmo,2014)

b. dinding penahan kantiliver, dimana dinding ini terdiri dari kombinasi dinding dengan beton bertulang yang berbentuk huruf $\mathrm{T}$. Ketebalan dari kedua bagian relatif tipis dan secara penuh diberi tulangan untuk menahan momen dan gaya lintang yang bekerja pada dinding tersebut. Stabilitas konstruksinya diperoleh dari berat sendiri dinding penahan dan berat tanah diatas tumit tapak (hell).

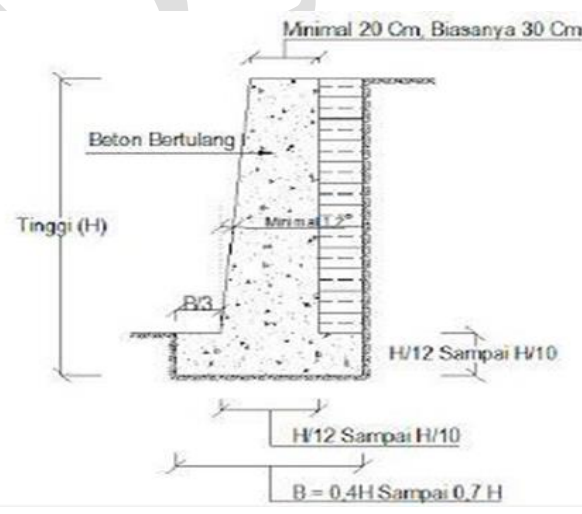

Gambar 2. Dinding Penahan Tanah Type Kantilever (Sumber : Hardiyatmo, 2014) c. dinding kontravort, dimana dinding ini terdiri dari dinding beton bertulang tipis yang di bagian dalam dinding pada jarak tertentu didukung oleh pelat/dinding vertikal (dinding penguat). Ruang di atas pelat pondasi diisi dengan tanah urug. Bila tekanan tanah aktif pada dinding vertical cukup besar, maka bagian dinding vertikal dan tumit perlu disatukan (kontrafort). Kontrafort berfungsi sebagai pengikat tarik dinding vertical dan ditempatkan pada bagian timbunan dengan interfal jarak tertentu

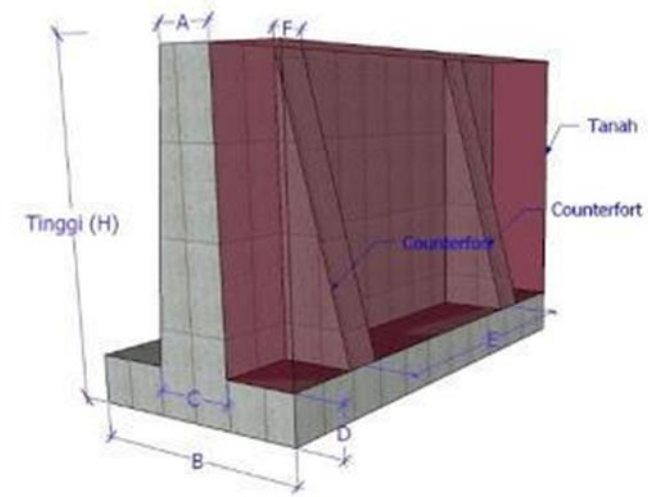

Gambar 3. Dinding Penahan Tanah Type Kounterfort (Sumber : Hardiyatmo, 2014)

d. dinding penahan tanah type buttress, dimana dinding Buttress hampir sama dengan dinding kontrafort, hanya bedanya bagian kontrafort diletakkan di depan dinding. Dalam hal ini, struktur kontrafort berfungsi memikul tegangan tekan.

\section{METODOLOGI}

Dalam analisa geoteknik pada daerah longsoran ruas jalan pada ruas jalan Tamba' Narang - Ulusalu pada tepatnya pada STA 4+150 dilakukan dengan beberapa tahap, dari persiapan pekerjaan, mempersiapan kebutuhan data,melakukan identifikasi masalah, melakukan studi pustaka, melakukan analisa data yang diperoleh di lapangan maupun pada pengujian di laboratorium serta melakukan pembahasan 


\section{DynamicSainT}

Jilid. V No. 1., April 2020

sehingga diperoleh hasil dan kesimpulanDalam analisa geoteknik pada daerah longsoran ruas jalan pada ruas jalan Tamba' Narang - Ulusalu pada tepatnya pada STA 4+150 dilakukan dengan beberapa tahap, dari persiapan pekerjaan, mempersiapan kebutuhan data,melakukan identifikasi masalah, melakukan studi pustaka, melakukan analisa data yang diperoleh di lapangan maupun pada pengujian di laboratorium serta melakukan pembahasan sehingga diperoleh hasil dan kesimpulan

\section{HASIL DAN PEMBAHASAN}

\subsection{Karakteristik Fisik Tanah}

Pemeriksaan karakteristik fisik tanah dilakukan dengan mengambil sampel tanah di 3 titik pada bidang longsor. Pemeriksaan sampel tanah dilakukan di Laboratorium Mekanika Tanah UKI Toraja dan diperoleh karakteristik fisik tanah sebagaimana terlihat pada tabel 1 .

Tabel 1. Karakteristik Fisik Tanah

\begin{tabular}{|c|c|c|c|}
\hline No & PENGUJIAN & HASIL & KETERANGAN \\
\hline 1 & KADAR AIR & $19.54 \%$ & BAIK \\
\hline \multirow[t]{4}{*}{2} & ANALISA SARINGAN & & \\
\hline & SAMPEL 1 & Lolos saringan $200=3.81 \%$ & \multirow{3}{*}{ - } \\
\hline & SAMPEL 2 & Lolos saringan $200=1.99 \%$ & \\
\hline & SAMPEL 3 & Lolos saringan $200=1.66 \%$ & \\
\hline \multirow[t]{5}{*}{3} & BATAS - BATAS ATTERBERG & & \\
\hline & SAMPEL 1 & & \\
\hline & BATAS CAIR & $67.48 \%$ & \multirow{3}{*}{ KOHESIF } \\
\hline & BATAS PLASTIS & $58.96 \%$ & \\
\hline & INDEKS PLASTISITAS & $8.52 \%$ & \\
\hline & \multicolumn{2}{|l|}{ SAMPEL 2} & \multirow{4}{*}{ KOHESIF } \\
\hline & BATAS CAIR & $59.67 \%$ & \\
\hline & BATAS PLASTIS & $50.51 \%$ & \\
\hline & INDEKS PLASTISITAS & $9.16 \%$ & \\
\hline \multicolumn{3}{|c|}{ SAMPEL 3} & \multirow{4}{*}{ KOHESIF } \\
\hline & BATAS CAIR & $56.79 \%$ & \\
\hline & BATAS PLASTIS & $48.11 \%$ & \\
\hline & INDEKS PLASTISITAS & $8.68 \%$ & \\
\hline 4 & BERAT JENIS & $2.6 \mathrm{Grm} / \mathrm{cm}^{3}$ & LEMPUNG ORGANIK \\
\hline \multirow[t]{9}{*}{5} & DAYA DUKUNG TANAH & & \\
\hline & PEMADATAN & & \\
\hline & SAMPEL 1 & $y d r y=1.085, W=23.65 \%$ & - \\
\hline & SAMPEL 2 & $y d r y=1.154, W=27.23 \%$ & - \\
\hline & SAMPEL 3 & $y d r y=1.244, W=23.89 \%$ & - \\
\hline & CBR & & \\
\hline & SAMPEL 1 & $13.21 \%$ & BAIK \\
\hline & SAMPEL 2 & $15 \%$ & BAIK \\
\hline & SAMPEL 3 & $13.21 \%$ & BAIK \\
\hline
\end{tabular}

\subsection{Analisa Bidang Longsor}

Berdasarkan data diperoleh panjang longsoran $(\mathrm{P})=28$ meter, lebar $(\mathrm{L})=\mathrm{L}=7.7$ meter, luas daerah longsoran $(\mathrm{A})=215.6 \mathrm{~m}^{2}$, besar sudut lereng $(\beta)$ pada lokasi penelitian $62^{0}$ dan $28^{\circ}$.

Pada perhitungan tegangan - tegangan yang bekerja pada tanah dipeoleh tegangan normal sebesar $=38.06 \mathrm{kN} / \mathrm{m}^{2}$ dan tegangan geser sebesar $=33.49 \mathrm{kN} / \mathrm{m}^{2}$. Sedangkan nilai kohesi tanah diperoleh $=13.25 \mathrm{kN} / \mathrm{cm}^{2}$.

\subsection{Analisa Stabilitas Lereng}

Stabilitas lereng dapat ditinjau dengan beberapa cara, namun tinjauan yang dipakai dengan cara lengkung Swedia atau dikenal dengan cara lengkungan gelincir, dapat dilihat pada Gambar 4.

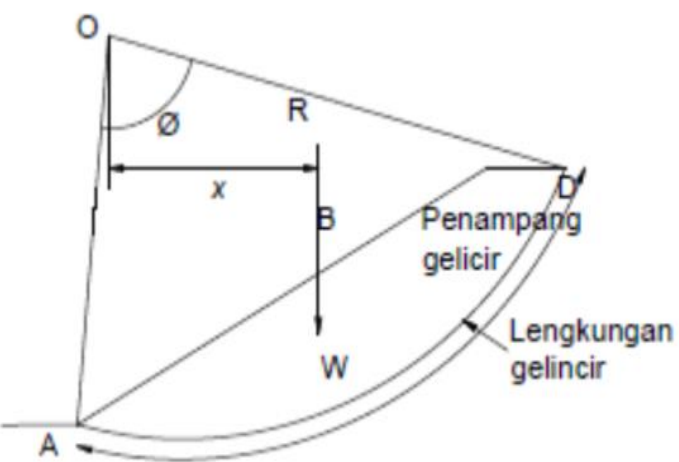

Gambar 4. Lengkungan Gelincir Kritis

Tinjau lengkungan gelincir $\mathrm{AD}$, dengan jari-jari R dan titik pusat perputaran O. Berat $\operatorname{tanah}=\mathrm{W}$ dalam satu-satuan tebal lebar.

a. Momen pendorong/penggerak $=\mathrm{M}_{\mathrm{D}}=$ Wx, dimana:

$$
\begin{aligned}
& \mathrm{x}=\text { Jarak pusat berat } \mathrm{W} \text { terhadap } \mathrm{O} \\
& \mathrm{c}=\text { Kohesi } \\
& \mathrm{L}=\text { Panjang lengkungan gelincir } \mathrm{AD}
\end{aligned}
$$
maka,

$$
\begin{aligned}
\mathrm{M}_{\mathrm{D}} & =\mathrm{W} . \mathrm{x} \\
& =(17.57 \times 12.44) \times 6.1 \\
& =1333.28
\end{aligned}
$$

b. Momen penahan $=M_{R}=c . L . R$, dimana:

$$
\begin{aligned}
\mathrm{R} & =\text { jari }- \text { jari } \\
\mathrm{C} & =\text { kohesi } \\
\mathrm{L} & =\text { panjang lengkungan gelincir }
\end{aligned}
$$




\section{DynamicSainT}

Jilid. V No. 1., April 2020

$$
\begin{aligned}
\mathrm{W} & =\text { berat tanah } \\
\mathrm{M}_{\mathrm{R}} & =13.25 \times 9.2 \times 9 \\
& =1097.1
\end{aligned}
$$

c. Untuk faktor keamanan

$$
\begin{aligned}
\text { FK } & =\frac{\text { Momen Penahan }}{\text { Momen Penggerak }} \\
\text { FK } & =\frac{1097.1}{1333.28} \\
& =0.82
\end{aligned}
$$

\subsection{Analisis Koefisien Tekanan Tanah Lateral Cara Coulomb}

Karena permukaan tanah urugan sejajar dengan permukaan dinding penahan tanah maka $\beta=0$ dan sudut kemiringan dinding penahan terhadap garis horizontal $\alpha=90^{\circ}$

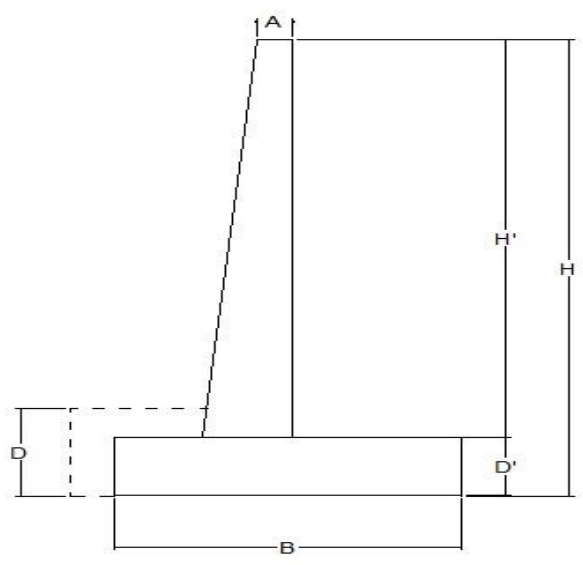

Gambar 5. Sketsa dinding penahan

1. Koefisien Tekanan Tanah Aktif

Untuk : $-\beta=0$

$$
\begin{aligned}
& -\alpha=90^{\circ} \\
& -\delta=(2 / 3) \times \varnothing=(2 / 3) \times 28^{\circ}= \\
& 18.66^{\circ}
\end{aligned}
$$

Maka :

$$
\mathrm{K}_{\mathrm{a}}=\frac{\sin ^{2}(\alpha+\varnothing)}{\sin ^{2} \alpha \sin (\alpha-\delta)\left(1+\sqrt{\frac{\sin (\varnothing+\delta) \sin (\varnothing-\beta)}{\sin (\alpha-\delta) \sin (\alpha+\beta)}}\right)} 2
$$

Dengan :

$$
\begin{array}{lll}
-\sin ^{2}(\alpha+\varnothing) & =\sin ^{2}(90+28) & =0.779 \\
-\sin ^{2} \alpha & =\sin ^{2} 90 & =1 \\
-\sin (\alpha-\delta) & =\sin (90-18.66) & =0.947 \\
-\sin (\varnothing+\delta) & =\sin (28+18.66) & =0.727 \\
-\sin (\varnothing-\beta)=\sin (28-0) & =0.469 \\
-\sin (\alpha+\beta)=\sin (90+0) & =1
\end{array}
$$

$$
\begin{gathered}
\mathrm{K}_{\mathrm{a}}=\frac{0.779}{1 \times 0.947\left(1+\sqrt{\frac{0.727 \times 0.469}{0.947 \times 1}}\right)} 2 \\
\mathrm{~K}_{\mathrm{a}}=0.321
\end{gathered}
$$

2. Koefisien Tekanan Tanah Pasif

$$
\mathrm{K}_{\mathrm{P}}=\frac{\sin ^{2}(\alpha-\varnothing)}{\sin ^{2} \alpha \sin (\alpha+\delta)\left(1-\sqrt{\frac{\sin (\varnothing+\delta) \sin (\varnothing+\beta)}{\sin (\alpha+\delta) \sin (\alpha+\beta)}}\right)} 2
$$

Dengan :

$$
\begin{aligned}
& -\sin ^{2}(\alpha-\varnothing) \quad=\sin ^{2}(90-28) \quad=0.779 \\
& \begin{array}{lll}
-\sin ^{2} \alpha & =\sin ^{2} 90 \quad=1
\end{array} \\
& -\sin (\alpha+\delta)=\sin (90+18.66)=0.947 \\
& -\sin (\varnothing+\delta)=\sin (28+18.66) \quad=0.727 \\
& -\sin (\varnothing+\beta)=\sin (28+0) \quad=0.469 \\
& -\sin (\alpha+\beta) \quad=\sin (90+0) \quad=1
\end{aligned}
$$

$$
\begin{aligned}
& \mathrm{K}_{\mathrm{P}}=\frac{0.779}{1 \times 0.947\left(1-\sqrt{\frac{0.727 \times 0.469}{0.947 \times 1}}\right)} \\
& \mathrm{K}_{\mathrm{p}}=5.193
\end{aligned}
$$

\subsection{Analisis Tekanan Tanah Pada Dinding Penahan Tanah}

1. Tekanan Tanah Aktif

Akibat beban tambahan merata $\left(\mathrm{Pa}_{1}\right)$

$$
\begin{aligned}
\mathrm{hs} & =\mathrm{q} / \gamma=12 / 12.44=0.96 \mathrm{~m} \\
\mathrm{~Pa}_{1} & =\mathrm{ka} \cdot \gamma \cdot \mathrm{hs} . \mathrm{H} \\
& =0.321 \times 12.44 \times 0.96 \times 7.8 \\
& =29.90 \mathrm{KN} / \mathrm{m}
\end{aligned}
$$

Akibat beban tanah dibelakang dinding penahan $\left(\mathrm{Pa}_{2}\right)$

$$
\begin{aligned}
\mathrm{Pa}_{2} & =1 / 2 \cdot \mathrm{ka} \cdot \gamma \cdot \mathrm{H}^{2} \\
& =1 / 2 \times 0.321 \times 12.44 \times(7.8)^{2} \\
& =121.07 \mathrm{kN} / \mathrm{m}
\end{aligned}
$$

2. Tekanan Tanah Pasif

$$
\begin{aligned}
\mathrm{P}_{\mathrm{P}} & =1 / 2 \cdot \mathrm{kp} \cdot \gamma \cdot(\mathrm{D})^{2} \\
& =1 / 2 \times 5.193 \times 12.44 \times(1.5)^{2} \\
& =72.67 \mathrm{kN} / \mathrm{m}
\end{aligned}
$$




\section{DynamicSainT}

Jilid. V No. 1., April 2020

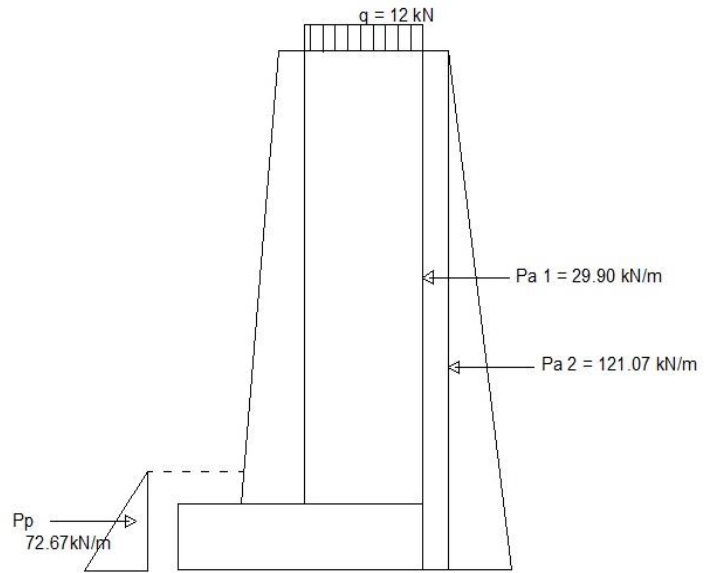

Gambar 6. Tekanan tanah aktif dan pasif pada dinding penahan

\subsection{Analisa Gaya Vertikal dan Momen Terhadap Kaki Depan Pondasi.}

Direncanakan lebar fondasi B $=4.7 \mathrm{~m}$, maka momen akibat gaya berat tembok penahan dapat dihitung seperti pada Tabel 4.37 di bawah:

Berdasarkan daftar berat isi material maka diketahui:

$\gamma$ beton bertulang $=24 \mathrm{kN} / \mathrm{m}^{3}$

$$
\gamma \text { tanah } \quad=12.44 \mathrm{kN} / \mathrm{m}^{3}
$$

Table 2. Perhitungan momen akibat gaya berat terhadap titik $\mathrm{O}$

\begin{tabular}{|c|c|c|c|c|}
\hline \multirow{2}{*}{ Bidang } & Luas & Berat & Lengan & Momen \\
& Penampang & & & \\
\hline W1 & 2.04 & 48.96 & 1.80 & 88.03 \\
\hline W2 & 2.72 & 65.28 & 2.4 & 156.672 \\
\hline W3 & 4.7 & 112.8 & 2.35 & 265.08 \\
\hline W4 & 14.28 & 177.6 & 3.65 & 648.398 \\
\hline W5 & 0.8 & 9.952 & 0.8 & 7.9616 \\
\hline W & & 25.2 & 3.65 & 91.98 \\
\hline & \multicolumn{2}{|c|}{$\Sigma=439.83$} & \multicolumn{2}{|l}{$\Sigma \mathrm{MW}=1258.12$} \\
\hline
\end{tabular}

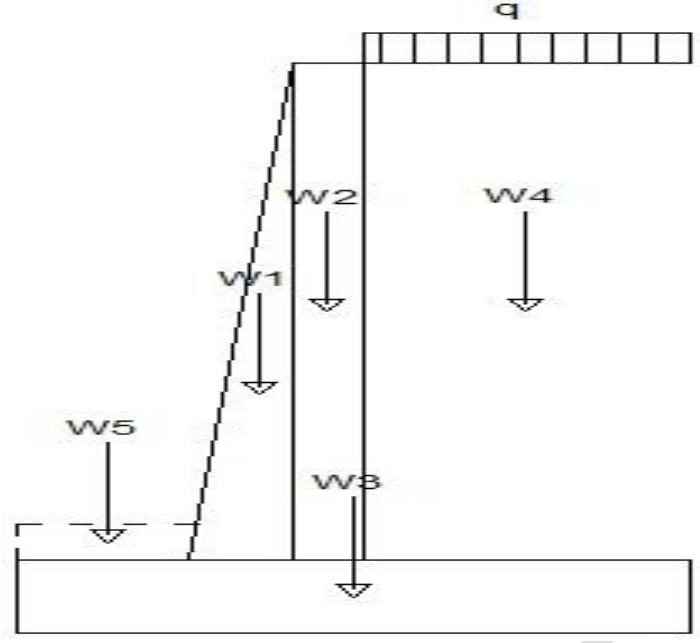

Gambar 7. Momen pada dinding penahan

\subsection{Analisa momen akibat beban lateral} Momen pengguling ( Mo)

$$
\begin{aligned}
\text { Mo } & =\left(\mathrm{Pa}_{1} . \mathrm{H} / 2\right)+\left(\mathrm{Pa}_{2} . \mathrm{H} / 3\right) \\
& =(29.90 \times 3.9)+(314.78 \times 2.6) \\
& =431.39 \mathrm{kN} / \mathrm{m}
\end{aligned}
$$

\subsection{Cek nilai eksentrisitas}

Titik kerja gaya resultan (R) dihitung darititik $\mathrm{O}$ adalah :

$$
\begin{aligned}
\mathrm{d} & =\frac{\Sigma \mathrm{Mw}-\Sigma \mathrm{Mo}}{\Sigma \mathrm{w}} \\
& =\frac{1258.12-431.39}{439.83} \\
& =1.87 \mathrm{~m}
\end{aligned}
$$

Nilai eksentrisitas

$$
\begin{aligned}
& \mathrm{e}=\frac{\mathrm{B}}{2} \mathrm{~d} \\
& \mathrm{e}=\frac{3.9}{2}-1.87 \\
& \mathrm{e}=0.48 \mathrm{~m}
\end{aligned}
$$

Karena nilai $\mathrm{e}=0.48 \mathrm{~m} \leq \mathrm{B} / 6=1.56 \mathrm{~m}$, berarti lebar pondasi $\mathrm{B}=4.7 \mathrm{~m}$ memenuhi syarat, sehingga nilai qmin dan qmax dapat dihitung dengan persamaan :

$$
\begin{aligned}
& \mathrm{q}=\frac{\Sigma \mathrm{w}}{\mathrm{B}}\left(1+\frac{6 . \mathrm{e}}{\mathrm{B}}\right) \\
& \mathrm{q}=\frac{457.47}{4.7}\left(1+\frac{6 \times 0.48}{4.7}\right)
\end{aligned}
$$




\section{DynamicSainT}

Jilid. V No. 1., April 2020

$$
\begin{aligned}
& \mathrm{q}=150.92 \mathrm{kN} / \mathrm{m}^{2} \\
& \mathrm{q}=\frac{\Sigma \mathrm{w}}{\mathrm{B}}\left(1-\frac{6 . \mathrm{e}}{\mathrm{B}}\right) \\
& \mathrm{q}=\frac{457.47}{4.7}\left(1-\frac{6 \times 0.48}{4.7}\right) \\
& \mathrm{q}=36.23 \mathrm{kN} / \mathrm{m}^{2}
\end{aligned}
$$

Untuk nilai $\mathrm{B}^{\prime}=\mathrm{B}-2 \mathrm{e}$

$$
\begin{aligned}
& =4.7-2 \times 0.48 \\
= & 3.74 \mathrm{~m}
\end{aligned}
$$

Untuk nilai $\mathrm{q}^{\prime}=\frac{\Sigma \mathrm{w}}{\mathrm{B}}$

$$
\begin{aligned}
& q^{\prime}=\frac{493.83}{3.74} \\
& q^{\prime}=132.04 \mathrm{kN} / \mathrm{m}^{2}
\end{aligned}
$$

\subsection{Perhitungan Terhadap Kestabilan Tembok Penahan}

Dalam perhitungan stabilitas tembok penahan digunakan $\mathrm{Pa}$ dan $\mathrm{Pp}$ teori Coulomb).

1. Kestabilan terhadap guling (overturming). Diketahui :

- Jumlah momen tahanan $\left(\sum \mathrm{M}_{\mathrm{w}}\right)$

$$
\sum \mathrm{M}_{\mathrm{w}}=1258.12 \mathrm{kN} / \mathrm{m}
$$

- Jumlah momen guling $\left(\sum \mathrm{M}_{\mathrm{o}}\right)$

$$
\sum \mathrm{M}_{\mathrm{o}}=431.39 \mathrm{kN} / \mathrm{m}
$$

Maka faktor keamanan terhadap bahaya guling (Fs overturning) dapat dihitung dengan persaman:

$$
\begin{aligned}
& \mathrm{Fgl}=\frac{\Sigma \mathrm{Mw}}{\Sigma \mathrm{Mo}} \\
& \mathrm{Fgl}=\frac{1258.12}{431.39} \\
& \mathrm{Fgl}=2.91
\end{aligned}
$$

Karena $\mathrm{Fgl}=2.91>1.5$ berarti aman terhadap bahaya guling.

2. Kestabilan terhadap gaya geser (sliding) Nilai gaya geser (Vo)

$$
\begin{aligned}
\mathrm{Vo}_{0} & =\mathrm{Pa}_{1}+\mathrm{Pa}_{2} \\
& =29.90+121.07
\end{aligned}
$$

$$
=150.97 \mathrm{kN}
$$

Nilai gaya penahan $(\mathrm{Vb})$

$$
\begin{aligned}
\mathrm{Vb} & =\mathrm{R}+\mathrm{Pp} \\
& =439.83+72.67 \\
& =512.5 \mathrm{kN}
\end{aligned}
$$

Maka faktor keamanan terhadap geser (Fssliding) dapat dihitung dengan persaman :

$$
\begin{aligned}
& \mathrm{Fgs}=\frac{\Sigma \mathrm{Vb}}{\Sigma \mathrm{Vo}_{\mathrm{o}}} \\
& \mathrm{Fgs}=\frac{512.5}{150.97} \\
& \mathrm{Fgs}=3.39
\end{aligned}
$$

Karena Fgs $=3.39>1.5$ berarti aman terhadap bahaya geser.

3. Stabilitas terhadap keruntuhan kapasitas dukung tanah. Dalam hal ini akan digunakan metode Terzaghi. Pada perhitungan ini dianggap pondasi terletak pada kedalaman 1 meter dari permukaan, dimana untuk nilai $\varnothing=28^{\circ}$ dari tabel perbandingan factor - factor daya Terzaghi diperoleh

$$
\mathrm{N}_{\mathrm{c}}=31.16, \mathrm{~N}_{\mathrm{q}}=17.81, \mathrm{~N}_{\gamma}=15.15,
$$

sehingga

$$
\begin{aligned}
& q_{u t}=c \cdot N_{c}+D_{f} \cdot \gamma N_{q}+0.5 \cdot \gamma \cdot B \cdot N_{\gamma} \\
& =(13.25 \times 31.16)+(1 \times 12.44 \times 17.8) \\
& +(0.5 \times 12.44 \times 4.7 \times 15.15) \\
& =1083.28 \mathrm{kN} / \mathrm{m}^{2}
\end{aligned}
$$

Maka faktor aman terhadap keruntuhan kapasitas daya dukung :

$$
\begin{aligned}
& F=\frac{\text { qult }}{q^{\prime}} \\
& F=\frac{1083.28}{132.04} \\
& F=8.2
\end{aligned}
$$

Karena Fgs $=8.2>3$ berarti aman terhadap 


\section{DynamicSainT}

Jilid. V No. 1., April 2020

bahaya keruntuhan kapasitas daya dukung.

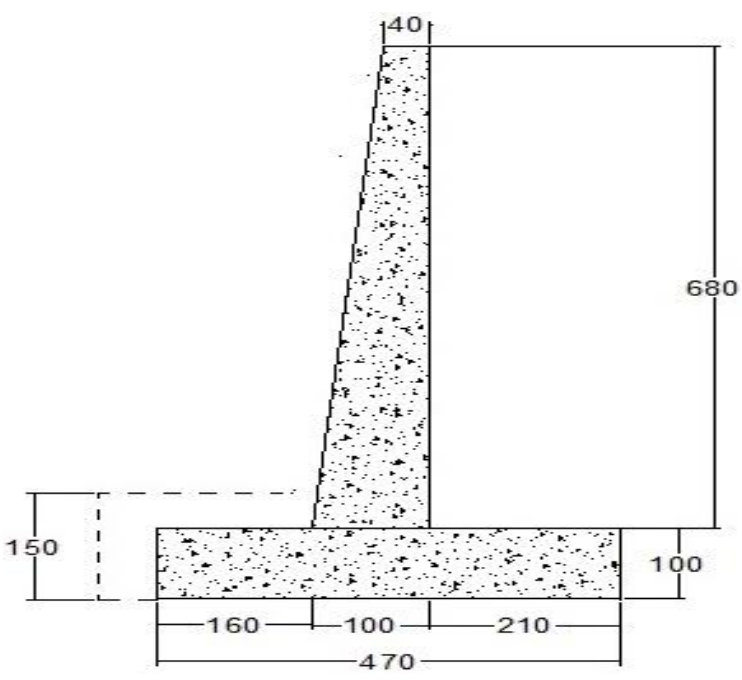

Gambar 8. Dimensi dinding penahan

\section{KESIMPULAN}

Dari hasil analisa maka dapat ditarik beberapa kesimpulan sebagai berikut :

1. Dari hasil pengujian di laboratorium diperoleh berat jenis $2.6 \mathrm{gr} / \mathrm{cm} 3$, sehingga tanah tersebut tergolong tanah lunak jenis tanah lempung organik dimana tanah tersebut memiliki kepadatan yang rendah sehinggah apabila mendapat beban atau tekanan maka akan menjadi tidak stabil, sehingga mengakibatkan terjadinya longsor di lokasi tersebut.

2. Perencanaan perkuatan tanah metode coulomb adalah dengan menggunakan dinding penahan tipe kantilever dimana analisa kestabilan tanah dengan cara coulomb untuk tekanan tanah lateral di peroleh koefisien tekanan tanah aktif, Ka $=0.321$ dan koefisien tekanan tanah pasif, $\mathrm{Kp}=5.193$, untuk tekanan tanah aktif pada dinding penahan, $\mathrm{Pa}=150.97 \mathrm{kN} / \mathrm{m}$ dan tekanan tanah pasif pada dinding penahan, $\mathrm{Pp}=72.67 \mathrm{kN} / \mathrm{m}$.

3. Hasil analisa perencanaan dinding penahan tanah dengan cara Coulomb untuk kelongsoran /keruntuhan yang terjadi, diperoleh nilai faktor keamanan terhadap guling adalah $\mathrm{Fgl}=2.91$ (Aman),
Untuk analisa terhadap gaya geser adalah Fgs $=3.39$ (Aman) dan nilai faktor keamanan terhadap keruntuhan kapasitas daya dukung tanah adalah $\mathrm{FK}=8.2$ ( Aman).

\section{DAFTAR PUSTAKA}

1. Bowles, E.J, 1989, Sifat-sifat Fisik Tanah, Penerbit Erlangga, Jakarta

2. Culmann,1975, Mekanika Tanah, Penerbit Erlangga.

3. Craig, R. F., 1986, Mekanika Tanah. Edisi Keempat, Erlangga, Jakarta.

4. Das, Braja M, 1994, Mekanika Tanah Jilid II, Penerbit Erlangga

5. Fathani, T. F., (2007), Longsor dan Gerakan Tanah, Bahan Kuliah MPBA FTSLUGM, Yogyakarta.

6. Hardiyatmo, H.C., 2018, Mekanika Tanah II, Gadjah Mada University Press, Yogyakarta.

7. Hardiyatmo, H.C., 2004, Tanah Ekspansif Permasalahan dan Penanganan, Gadjah Mada University Press, Yogyakarta.

8. Jacob Bokko, Johan, Parea Rusan R, Erick Bunga, 2019, Analisis Kelongsoran Jalan Poros Sangalla-Batualu Dengan Program Plaxis, Jurnal Dynamic Saint, IV(1), 764772 ,

http://www.journals.ukitoraja.ac.id/index. php/dynamicsaint/article/view/690/528

9. Nugroho, 2005, Mekanika Tanah, Erlangga, Jakarta.

10. Suryolelono, K.B. 2002, Perencanaan Fondasi. Nafiri. Yokyakarta.

11.Sutikno, 1997. Penanggulangan Tanah Longsor. Bahan Penyuluhan Bencana Alam Gerakan Tanah. Jakarta

12.Wesley, L.D. 2017. Mekanika Tanah. Penerbit Andi, Jakarta. 